\title{
Differential effects of sex steroid hormones on the expression of multiple first exons including a novel first exon of prolactin receptor gene in the rat liver
}

\author{
M Tanaka, M Suzuki', T Kawana', M Segawa1', M Yoshikawa, M Mori, M Kobayashi, \\ N Nakai ${ }^{1}$ and T R Saito ${ }^{2}$ \\ Department of Animal Science, Faculty of Applied Life Science, Nippon Veterinary and Animal Science University, Musashino, Tokyo 180-8602, Japan \\ ${ }^{1}$ Department of Biochemistry, Faculty of Medicine, Mie University, Tsu, Mie 514-8507, Japan \\ ${ }^{2}$ Department of Laboratory Animal Sciences, Faculty of Veterinary Medicine, Nippon Veterinary and Animal Science University, Musashino, Tokyo 180-8602, Japan
}

(Requests for offprints should be addressed to M Tanaka; Email: mitanaka@nvau.ac.jp)

\begin{abstract}
In addition to the known four alternative first exons $\mathrm{E} 1_{1}, \mathrm{E} 1_{2}, \mathrm{E} 1_{3}$ and $\mathrm{E} 1_{4}$ of the rat prolactin receptor (PRL-R) gene, a novel first exon, $E 1_{5}$, was identified by cDNA cloning of the $5^{\prime}$-end region of PRL-R mRNA in the rat liver. Genomic fragments containing $E 1_{5}$ and its $5^{\prime}$ - or $3^{\prime}$-flanking regions were also cloned from rat kidney genomic DNA. A sequence search for $E 1_{5}$ revealed that $E 1_{5}$ is located $49 \mathrm{~kb}$ upstream of exon 2 of the PRL-R gene in rat chromosome $2 q 16$. RT-PCR analysis revealed that $E 1_{5}$ was preferentially expressed in the liver, brain and kidney. Expression profiles of $E 1_{2}^{-}, E 1_{3}-$ and $E 1_{5}-P R L-R$ mRNAs in the liver of male and female rats at 5 days of age and those at 8 weeks of age were examined by RT-PCR. The levels of $E 1_{2}-P R L-R$ mRNA in the female rat increased remarkably in rats at 8 weeks of age compared with those at 5 days of age, and the levels of $E 1_{5}-P R L-R$ mRNA in the male rat decreased markedly at 8 weeks of age compared with those at 5 days of age. In the female rat, the levels of $E 1_{2}-P R L-R$ mRNA at 8 weeks of age decreased with ovariectomy performed at 4 weeks of age and recovered with the administration of $\beta$-oestradiol. On the contrary, the levels of $\mathrm{E}_{5}-\mathrm{PRL}-\mathrm{R}$ mRNA increased with ovariectomy and decreased with the oestrogen treatment. In the male rat liver, the levels of $E 1_{2}-P R L-R$ mRNA at 8 weeks of age increased strikingly with castration performed at 4 weeks of age and became undetectable with the administration of testosterone. The levels of $\mathrm{E}_{5}$-PRL-R mRNA increased slightly with castration and were restored by testosterone treatment. Removal of gonadal tissues and sex steroid hormone treatment had no effect on the expression levels of $E 1_{3}-P R L-R$ mRNA in both female and male rat livers. These results indicated that the expression of the PRL-R gene in the liver is regulated by the differential effects of sex steroid hormones on the transcription of the multiple first exons including the novel one.
\end{abstract}

Journal of Molecular Endocrinology (2005) 34, 667-673

\section{Introduction}

Prolactin (PRL) has many physiological functions in vertebrates (Doppler 1994, Freeman et al. 2000). The actions of PRL are mediated by the PRL receptor (PRL-R), which belongs to the type 1 cytokine receptor superfamily (Kelly et al. 1991). In mammals, the long and short forms of PRL-R differing in the length and sequences of their cytoplasmic domains are generated by alternative splicing of a primary transcript from a single PRL-R gene (Boutin et al. 1988, Davis \& Linzer 1989, Shirota et al. 1990, Bignon et al. 1997, Schuler et al. 1997). The expression of the PRL-R gene is regulated by complex mechanisms. Multiple alternative first exons encoding $5^{\prime}$-untranslated regions have been identified in rat and human PRL-R genes, and the distinct expression patterns of these first exons are controlled by promoters located in the upstream regions of each first exon. In the rat PRL-R gene, three distinct first exons $\mathrm{E} 1_{1}, \mathrm{E} 1_{2}$ and
$\mathrm{E}_{3}$, together with their promoter regions PI, PII and PIII, have been identified (Hu et al. 1996, Moldrup et al. 1996). These three exons are located in the order of $\mathrm{E} 1_{3}$, $\mathrm{E} 1_{1}, \mathrm{E} 1_{2}$ from the distal side of exon 2 of the PRL-R gene (Hu et al. 1998a). $\mathrm{E} 1_{1}$ and $\mathrm{E} 1_{2}$ are predominantly expressed in gonadal tissues and liver respectively, while $\mathrm{E} 1_{3}$ is expressed in a wide range of tissues ( $\mathrm{Hu}$ et al. 1996). The gonad-specific expression of $\mathrm{E} 1_{1}$ is dependent on the activation of its promoter by steroidogenic factor I (Hu et al. 1997), and hepatocyte nuclear factor 4 (HNF4) participates in the expression of $\mathrm{E}_{2}$ in the liver (Moldrup et al. 1996). The activation of the $\mathrm{E} 1_{3}$ promoter by the transcription factors $\mathrm{C} / \mathrm{EBP} \beta$ and $\mathrm{SP} 1$ accounts for the generic expression of $\mathrm{E}_{3}(\mathrm{Hu}$ et al. 1998b). We have recently found another first exon, $\mathrm{E}_{4}$, which is preferentially expressed in the brain, though its location in the rat PRL-R gene is not known (Tanaka et al. 2002). In the human PRL-R gene, six alternative first exons, $\mathrm{hE} 1_{3}, \mathrm{hE} 1_{\mathrm{N} 1} \mathrm{hE} 1_{\mathrm{N} 2}, \mathrm{hE} 1_{\mathrm{N} 3}, \mathrm{hE} 1_{\mathrm{N} 4}$ and 
$\mathrm{hE}_{\mathrm{N} 5}$, have been identified (Hu et al. 1999, 2002). $\mathrm{hE} 1_{3}$ is considered to be the counterpart of rat $\mathrm{E}_{3}$ because its promoter shows high sequence similarity to that of rat $\mathrm{E} 1_{3}$ and shows high activity in various human tissues. The other five first exons show unique expression profiles in human tissues such as liver, ovary, testis and in a breast cancer cell line, T47D cells.

The presence of the multiple first exons allows the PRL-R gene to be regulated in different ways in individual tissues. We have previously demonstrated that the higher levels of PRL-R mRNA in the rat brain in late pregnancy and the following lactating period are dependent on the expression of $\mathrm{E}_{4}$ (Sugiyama et al. 1994, Tanaka et al. 2002). It has also been shown that the expression levels of PRL-R mRNA in the different brain regions are regulated by oestrogen, which increases the utilization of $\mathrm{E} 1_{2}$ and $\mathrm{E} 1_{3}$ first exons ( $\mathrm{Pi}$ et al. 2003). In the liver, the expression of the PRL-R gene is known to be regulated by sex steroid hormones; up-regulation by oestrogen and down-regulation by testosterone (Jolicoeur et al. 1989, Sakaguchi et al. 1994). However, the molecular mechanisms of the effects of the sex steroid hormones on the expression of the PRL-R gene in the liver are not yet known.

In the present study, we have identified a novel first exon, $\mathrm{E} 1_{5}$ of the rat PRL-R gene, and have examined the effects of sex steroid hormones on the expression of $\mathrm{E} 1_{2}, \mathrm{E} 1_{3}$ and $\mathrm{E} 1_{5}$ first exons in the liver.

\section{Materials and methods}

\section{Animals and hormone treatment}

Sprague-Dawley rats were purchased from SLC (Sizuoka, Japan) and housed in a temperature-controlled room with $12 \mathrm{~h}$ light and $12 \mathrm{~h}$ darkness. Food and water were available ad libitum.

Castration or ovariectomy was performed on 4-weekold rats, and hormone treatment was started 2 weeks after surgery. Five micrograms of $17 \beta$-oestradiol (Nacalai Tesque, Kyoto, Japan) in $0 \cdot 1 \mathrm{ml}$ olive oil, $1 \mathrm{mg}$ testosterone propionate (Nakalai Tesque) in $0.1 \mathrm{ml}$ olive oil, or $0 \cdot 1 \mathrm{ml}$ olive oil alone were injected subcutaneously into the back of the neck. The hormone injection was carried out daily for 2 weeks. The animals were killed by decapitation $24 \mathrm{~h}$ after the last injection and the liver was rapidly removed and frozen in liquid nitrogen until used. All procedures were performed in accordance with the NIH guidelines regarding the principles of animal care.

\section{cDNA cloning for 5'-regions of PRL-R mRNAs in the rat brain}

Total RNA was extracted from the liver with the ISOGEN kit (Nippon Gene, Toyama, Japan), and poly $(\mathrm{A})^{+}$RNA was isolated with oligotex-dT30 (TAKARA,
GCAGGCTGTTACTACATGTGTTGTGACTGACACCACAACCAGCTAAAGGA 50 СACTTCTCTGTGAAGGTGAGCACTGCAGATGTTTTGCACATGAGCCCTGA 100 AGGGAGCCTCTGATACATTGCCTATAGCAAGAAGAAGGGGCCAACCTGAA 150 GAAAAACATGCCATCTGCACTTGCTTTCGTCCTACTTGTTCTCAACATCA 200 GCCTCCTGAAGGGACAGTCACCACCAGGGAAACCTGAGATCCACAAATGT 250 CGCTCTCCTGACAAGGAAACATTCACCTGCTGGTGGAATCCTGGGACAGA 300 TGGAGGACTTCCTACCAATTATTCACTGACTTACAGCAAAGAAGGAGAGA 350 AAACCACCTACGAATGTCCAGACTACAAAACCAGTGGCCCCAACTCCTGC 400 TTCTTTAGCAAGCAGTACACTTCCATCTGGAAAATATATATCATCACAGT 450 AAATGCCACGAACCAAATGGGAAGCAGTT

Figure 1 The nucleotide sequence of the $E 1_{5}-P R L-R$ mRNA obtained by the oligo-capping method. The region corresponding to the $\mathrm{E}_{5}$ first exon is underlined and the initiation codon ATG is indicated by bold letters.

Tokyo, Japan) according to the manufacturer's instructions. The 5'-end of the PRL-R cDNA was synthesized by the oligocapping method (Maruyama \& Sugano 1994) as previously described (Tanaka et al. 2002), cloned into pGEM-T Easy vector (Promega, Palo Alto, CA, USA) and sequenced.

\section{Cloning of the $\mathrm{E} 1_{5}$ exon-containing region of the rat PRL-R gene}

Genomic DNA was prepared from a rat testis by the SDS-proteinase $\mathrm{K}$ method, and $5^{\prime}$-flanking regions of $\mathrm{E}_{5}$ were cloned with an LA-PCR in vitro cloning kit (TAKARA) according to the manufacturer's instruction. Briefly, the genomic DNA was digested with EcoRI restriction enzyme, and ligated with EcoRI cassette. The 5 '-flanking region of $\mathrm{E} 1_{5}$ was then amplified by $\mathrm{PGR}$ with cassette primer $\mathrm{C} 1$ supplied by the manufacturer and primer 1 (5'-CTGGTTGTGGTGTCAGTCACAA-3') corresponding to the antisense sequence of nucleotides 21-42 of $\mathrm{E} 1_{5}$ cDNA (Fig. 1). The second PCR amplification was performed with cassette primer C2 supplied by the manufacturer and primer 2 (5'-TCAGTCACA ACACATGTAGTAAG-3') corresponding to the antisense sequence of nucleotides 8-30 of E $1_{5}$ CDNA. For the cloning of the 3 '-flanking region of $\mathrm{E} 1_{5}$, the inverse PGR method was employed (Ochman et al. 1990). The genomic DNA was digested with SacI restriction enzyme and self-ligated. The circularized DNA was subjected to the PCR with primer 3 (5'-AATGCTGGCTCGAGC TAGGTGTTT-3') corresponding to nucleotides -146 to - 122 and primer 4 (5'-TGCGTGTGTGAATAGGCT ACTGGCT- $3^{\prime}$ ) corresponding to the antisense sequence of nucleotides -1115 to -1091 of the $5^{\prime}$-flanking region of $\mathrm{E} 1_{5}$ (Fig. 2). The amplified DNA fragments were cloned into pGEM-T Easy vector and sequenced.

\section{RT-PCR analysis}

Total RNA $(10 \mu \mathrm{g})$ from rat tissues was reverse transcribed using oligo-dT primer (TAKARA) and the 
gaattcgattagttagctctgtccgtgaaaggacagtatattccatctgtctcacgcccaactgctcctctgggactggtagcatctgtgtcctctgatt - 1449 tctgctctttagaaaatcaatacccacatcatattgctaaccttcaaagagctcaaggagagtgacaggagggcaaattgctcccagggagctccag - 1349

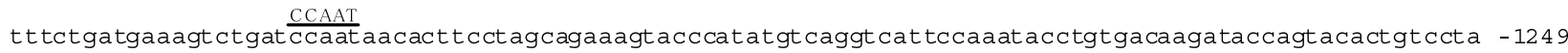
ccgattgtgtagtagtgactcttaaacagttacttagtaaccaagtgttgccatgggatcaaggcagaggagcatgttcatgagacacagggacttaac - 1149 aaggagagaggtggcttctaatcccatcttatagccagtaggctattcacacaggcagaccacaccctctaggcctcctattcttccttgggacatga - 1049 gaaccttgacccctcatcttgaagacatcttatccaccatcctcttatattgagaagtataatttctgaggctaagggtggagccagcaatcttc -949

tcaaaggttgagcttacaattatgtagttgacattctcaaacacttttaatcagagaggaatacagtaaattcattcatggaatgatcctgtatcc $\quad-849$ tattcatttaagtgggaaagtagacatacataatacatacatacatacatacatacatacatacatacatacatacattctcaagtatgcaggagaag $\quad$-749

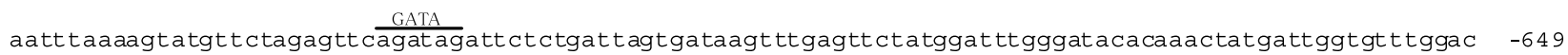
gtctagaagttaagatattatatgctatgagagaatggtgagctgagatggaagcttatgaagtaatgatattcagatatagaaattttttcatatcaca -549 atagtaatggagtcagtgcttcttccactgaagtcactgacaagcttcttgtgattggaaggaaaaaggtcatcagacattatgaaaaaggtgttagaaa -449 tgcatgtgtagaaattttcttatatgcaagattcactgagcttttttgtgaccatatatcccatccatagaaaatatgattaagtgctaaatccacaat -349 aactcaagctttggagccttggaaaattagctttagaaaaaaaatcacctggcaagctccatgtttccttttctcatcggatttttggaataggattag -249 ggtcaacagtaatttttaatctcaccaaaaaaaaccctatttcttacaaaactatctgtgtgcaagtttggttttccaacacggatccaggctgcca agaatgctggctccagctaggtctttgttagccaagtcaggggatggtcagggcattcatccaggtgacctgagccaaccccacccactcaaaaaaccaa - 39

gaggagtttgcctggtagagcaaggggcctcactgactGCAGGCTGTTACTACATGTGTTGTGACTGACACCACAACCAGgtatgtcatgagaaaacct 62

Figure 2 Nucleotide sequence of $E 1_{5}$ and its $5^{\prime}$-flanking region. The sequence of $E 1_{5}$ is shown in capitals. Transcription factor elements CCAAT, GATA and GAS are overlined.

resulting cDNA was subjected to 25 cycles $\left(\mathrm{E} 1_{2^{-}}, \mathrm{E} 1_{3^{-}}\right.$ and $\mathrm{E} 1_{5}$-PRL-R mRNAs) and 17 cycles (glyceraldehyde3-phosphate dehydrogenase (GAPDH)) of PCR $\left(94^{\circ} \mathrm{C}\right.$ for $1 \mathrm{~min}, 60^{\circ} \mathrm{C}$ for $1 \mathrm{~min}$ and $72{ }^{\circ} \mathrm{C}$ for $\left.1 \mathrm{~min}\right)$. Primer 5 (5'-AAGAACACTTGCGTGGCAAAGA GG-3', nucleotide positions -289 to -266 of $\mathrm{E}_{2}$ ( $\mathrm{Hu}$ et al. 1996) and primer 6 (5'-TTCGTGCTCTGTCT CACTCGCTCG-3', nucleotide positions -261 to -238 of $\mathrm{E}_{3}$ (Hu et al. 1996)) and primer 7 (5'-GCAGGCTGT TACTACATGTGTTG-3', nucleotide positions 1-23 of $\mathrm{E}_{5}$ cDNA in Fig. 1) were used as sense primers for the respective PRL-R mRNAs. Primer 8 (5'-GAAGAAGG GGCGAACCTGAAGAAAAAC-3', nucleotide positions $131-157$ of $\mathrm{E}_{5}$ cDNA in Fig. 1) was used as the sense primer for the analysis of total PRL-R mRNA. Primer 9 (5'-AACTGCTTCGCATTTGGTTGGTGG-3', nucleotide positions $456-479$ of $\mathrm{E}_{5}$ cDNA in Fig. 1) was used as the antisense primer for all of the PRL-R mRNAs. A sense primer (5'-TGAAGGTGGGTGTGA ACGGATTT- $3^{\prime}$ ) and an antisense primer (5'-CACA GTCTTCTGAGTGGCAGTGA-3') were used for the analysis of rat GAPDH mRNA. The PCR products were separated by electrophoresis on a $1.5 \%$ agarose gel and transferred to a nylon membrane. The membrane was subjected to Southern blot analysis with the AlkPhos direct labelling and detection system (Amersham Bioscience, Tokyo, Japan) according to the manufacturer's instruction. A cDNA fragment derived from a common region of E1 5 -PRL-R cDNA (nucleotides 131-479 in Fig. 1) was used as a probe. The fluorescent signal from the probe was detected on an X-ray film and the density of bands was measured by using the NIH image analysis system.

\section{Statistical analysis}

The data were analyzed for statistical significance using the Macintosh super ANOVA program and are expressed as the means \pm S.D. The significance of the differences between the values was analyzed using Scheffe's post-hoc test, and $P<0.05$ was considered significant.

\section{Results}

\section{Identification of a novel first exon, $\mathrm{E}_{5}$, in the rat PRL-R gene by cDNA and genomic DNA cloning}

Sequence analysis of the oligo-capping PRL-R cDNA clones obtained from the rat liver revealed the presence of a cDNA clone containing a unique sequence of $42 \mathrm{bp}$ at its 5 -end. The unique sequence in the cDNA is followed by the full-length exon 2 sequence, hence the unique sequence is considered to be derived from a novel first exon and is referred to as $\mathrm{E}_{5}$ (Fig. 1). The $5^{\prime}$ - and 3 '-flanking regions of $\mathrm{El}_{5}$ were cloned by PGR-based methods and sequenced (Fig. 2). A computer-assisted search revealed that $\mathrm{E}_{1}$ was localized between $\mathrm{El}_{2}$ and exon 2 in the draft sequence of the PRL-R gene located in chromosome 2q16 (Fig. 3). No canonical TATA box or GC box was observed but consensus sequences for transcription factors such as CCAAT, GATA and $\gamma$-interferon-activated sequence (GAS) were present in the $5^{\prime}$-flanking region. The splicing donor site sequence, gt, was observed immediately downstream of $\mathrm{E} 1_{5}$.

\section{Tissue distribution of $\mathrm{E}_{5}$-PRL-R mRNA}

Tissue distribution of $\mathrm{E}_{5}$-PRL-R mRNA was examined by RT-PGR. As shown in Fig. 4, a 349 bp fragment derived from $\mathrm{E} 1_{5}$-PRL-R mRNA was detected in the liver, brain and kidney, but not in the other tissues examined. 
PRL-R gene in rat chromosome $2 \mathrm{q} 16$

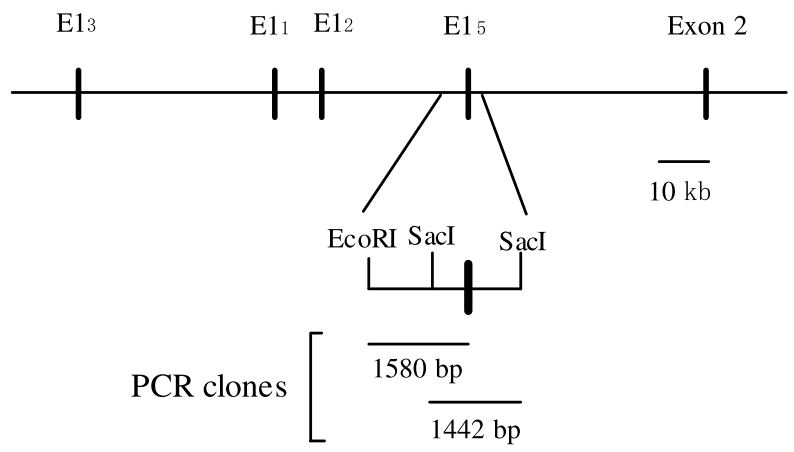

Figure 3 Schematic representation of the position of the $\mathrm{E} 1_{5}$ first exon in the rat PRL-R gene The positions of the four first exons and exon 2 in the rat genome draft sequence (NW 047622.1; National Center for Biotechnology Information, National Library of Medicine, Bethesda, MD, USA) are shown by thick vertical lines. $\mathrm{E} 1_{5}$ genomic clones obtained by PCR are indicated at the corresponding positions.

\section{Expression profiles of $\mathrm{E}_{2} \mathbf{2}^{-}, \mathrm{E} 1_{3}-$ and $\mathrm{E} 1_{5}-\mathrm{PRL}-\mathrm{R}$ mRNAs in the liver during sexual maturation}

Expression levels of $\mathrm{E}_{2^{-}}, \mathrm{E} 1_{3^{-}}$and $\mathrm{E} 1_{5}$-PRL-R mRNAs in the liver of male and female rats at 5 days of age and those at 8 weeks of age were examined by RT-PCR (Fig. 5). Levels of $\mathrm{E} 1_{2}$-PRL-R mRNA were faintly detected in the male rat liver at 5 days of age but were not detected at 8 weeks of age. In the female rat liver, the levels of $\mathrm{E} 1_{2}$-PRL-R mRNA were slightly higher than those in the male rat liver at 5 days of age, and increased remarkably at 8 weeks of age. The levels of E1 $1_{5}$-PRL-R mRNA did not differ with sex at 5 days of age, and decreased at 8 weeks of age with the male liver showing the higher extent. The levels of $\mathrm{E} 1_{3}$-PRL-R mRNA did not change with sex and age.

\section{Effects of sex steroid hormone treatments on the levels of $E 1_{2}-, E 1_{3}-$ and $E 1_{5}-P R L-R$ mRNAs in the liver}

The effects of sex steroid hormone treatments on the levels of $\mathrm{E}_{2_{2}}, \mathrm{E} 1_{3^{-}}$and $\mathrm{E} 1_{5}$-PRL-R mRNAs in the liver

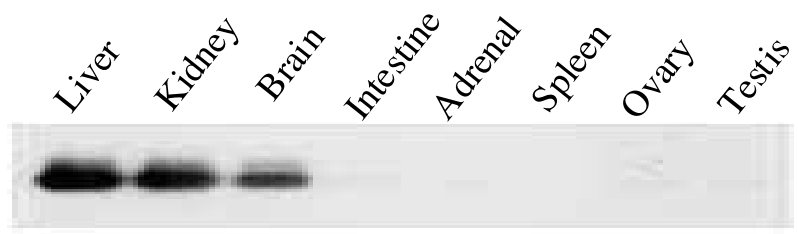

Figure 4 Tissue distribution of $E 1_{5}-\mathrm{PRL}-\mathrm{R}$ mRNA. Ten micrograms each of total RNA in the tissues of female and male (testis) rats at 8 weeks of age were reverse transcribed, and the E1 $1_{5}$-PRL-R cDNA was amplified by 25 cycles of PCR The $349 \mathrm{bp}$ of amplified cDNA fragment was hybridized with the AlkPhos-labelled PRL-R cDNA probe and the fluorescent signal from the probe was detected on an X-ray film.
(A)

$\mathrm{E} 12$

E13

E15

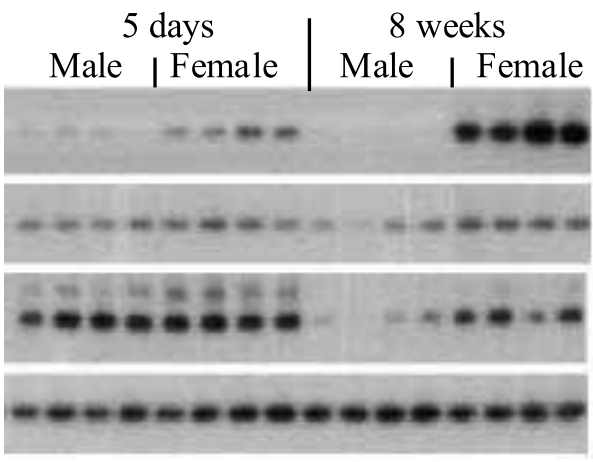

(B)
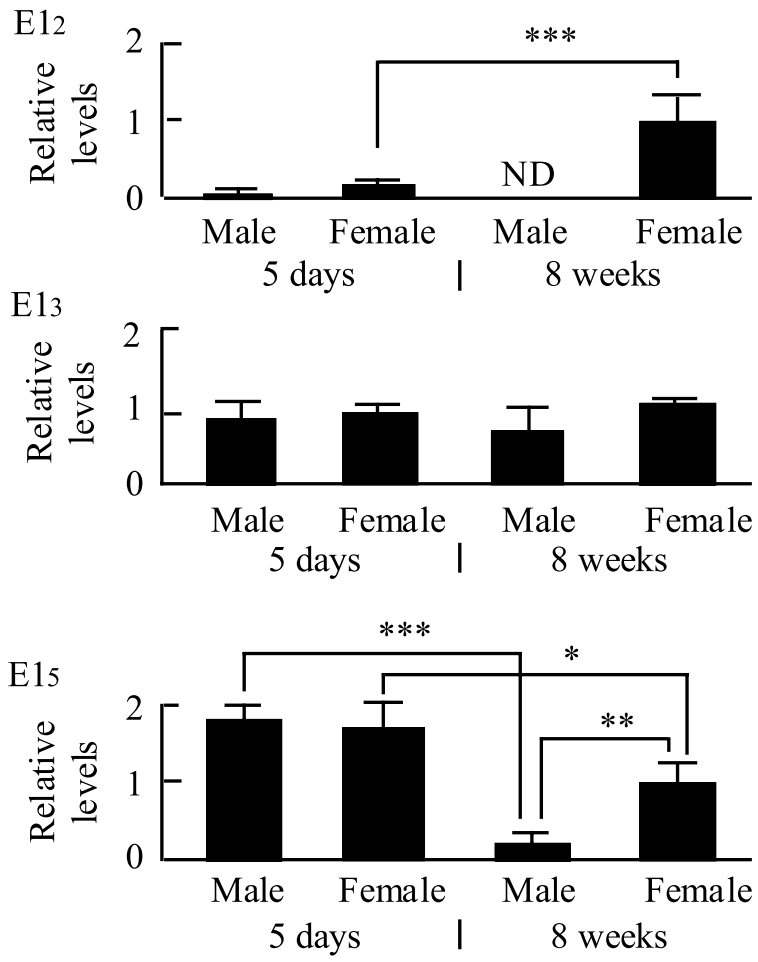

Figure 5 Expression profiles of $\mathrm{E}_{2} \mathrm{2}^{-}, \mathrm{E} 1_{3}-$ and $\mathrm{E} 1_{5}-\mathrm{PRL}-\mathrm{R}$ mRNAs in the liver of male and female rats at 5 days of age and 8 weeks of age. (A) Autoradiograms of RT-PCR Southern blot analysis of $\mathrm{E}_{2^{2}}-\mathrm{E} 1_{3}$ - and $\mathrm{E} 1_{5}-\mathrm{PRL}-\mathrm{R}$ mRNAs and GAPDH mRNA with four rats in each group. (B) Densities of the hybridization signals were measured and expressed as the values relative to the value of each PRL-R mRNA of female rats at 8 weeks of age. Each value represents the mean \pm S.D. ${ }^{\star} P<0.05,{ }^{* \star} P<0.01,{ }^{* \star *} P<0.001, \mathrm{ND}$, not detected.

were investigated (Figs 6 and 7). Two weeks after castration or ovariectomy of 4-week-old rats, $17 \beta$ oestradiol or testosterone propionate was subcutaneously administered daily for 2 weeks, and the levels of the PRL-R mRNAs were examined by RT-PGR 1 day after the final administration. In the female rat liver, the levels 
(A)

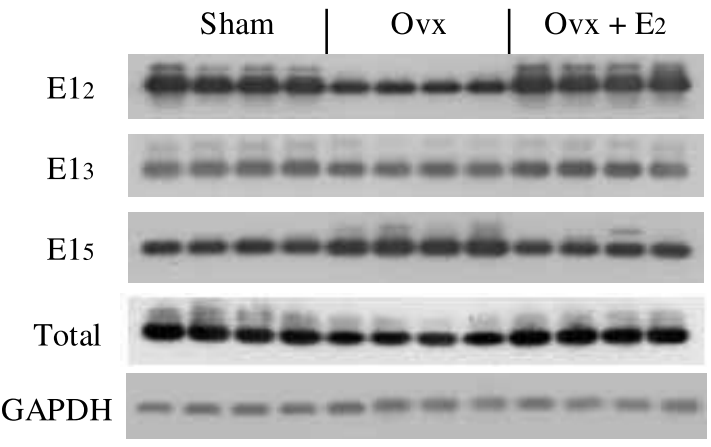

(B)

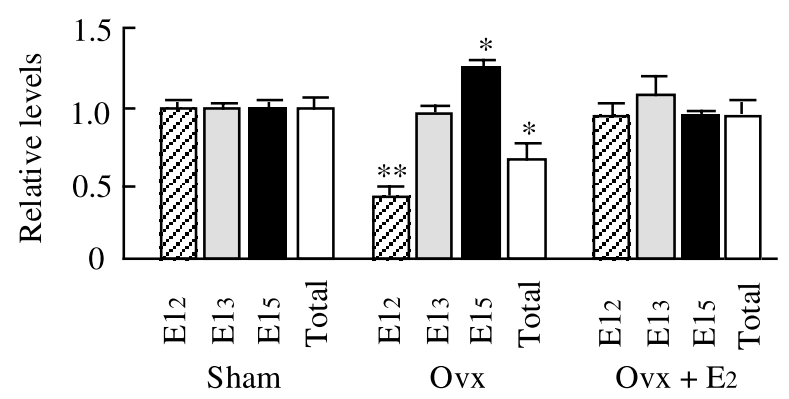

Figure 6 Effect of oestrogen (E2) treatment on the expression levels of $E 1_{2}-\mathrm{E}_{3}{ }^{-}$and $\mathrm{E} 1_{5}-\mathrm{PRL}-\mathrm{R} \mathrm{mRNAs}$ in the liver of female rats. (A) Autoradiograms of RT-PCR Southern blot analysis of $\mathrm{E}_{2^{-}}, \mathrm{E} 1_{3}-, \mathrm{E} 1_{5}$ - and total PRL-R mRNAs and GAPDH mRNA with four rats in each group. (B) Densities of the hybridization signals were measured and expressed as values relative to the value of each PRL-R mRNA of the sham-operated group. Each value represents the mean \pm S.D. ${ }^{*} P<0.05,{ }^{* *} P<0.01$ vs the sham-treated group. Ovx, ovariectomized.

of $\mathrm{E} 1_{2}$-PRL-R mRNA decreased significantly with ovariectomy and recovered with oestrogen treatment. On the other hand, the levels of E1 $1_{5}$-PRL-R mRNA increased slightly with surgery, and decreased to the levels of sham-operated rats with oestrogen administration. The levels of $\mathrm{E}_{3^{-}}$and total PRL-R mRNAs were not affected by ovariectomy and hormone treatment. In the male rat liver, the levels of $\mathrm{E} 1_{2}$-PRL-R mRNA increased strikingly with castration and decreased to the levels of sham-operated animals with the administration of tetosterone. The levels of $\mathrm{E} 1_{5}$-PRL-R mRNA slightly increased with castration and were restored by testosterone treatment, while castration and testosterone treatment had no effect on the levels of $\mathrm{E}_{3}$-PRL-R mRNAs. The profile of the total PRL-R mRNA was similar to that of $E 1_{2}$-PRL-R mRNA.

\section{Discussion}

In addition to the known four first exons, $\mathrm{E} 1_{1}, \mathrm{E} 1_{2}, \mathrm{E} 1_{3}$ and $\mathrm{E} 1_{4}$, a novel first exon $\mathrm{E} 1_{5}$ was identified in the rat
(A)

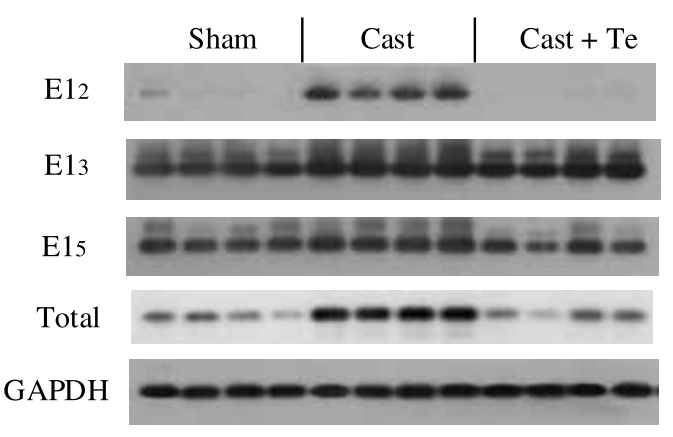

(B)

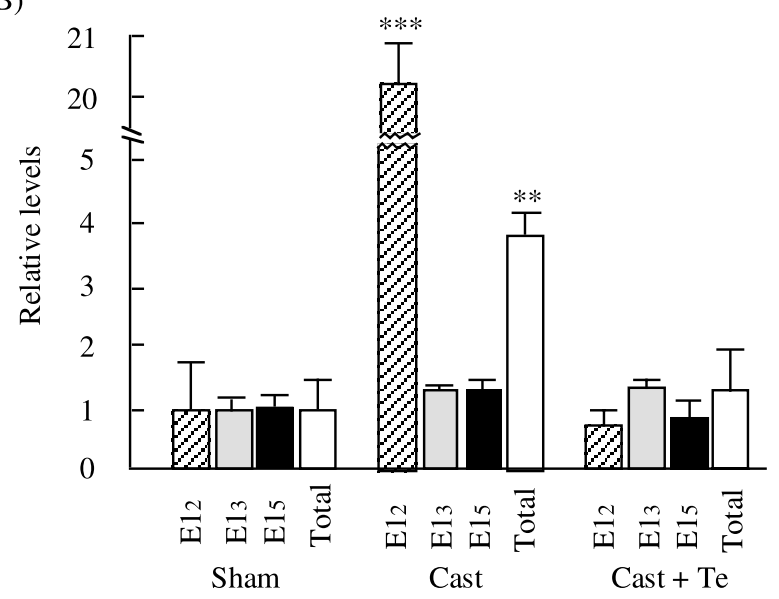

Figure 7 Effect of testosterone $(\mathrm{Te})$ treatment on the expression levels of $E 1_{2}-, E 1_{3}$ - and $E 1_{5}-\mathrm{PRL}-\mathrm{R}$ mRNAs in the liver of male rats. (A) Autoradiograms of RT-PCR Southern blot analysis of $\mathrm{E1}_{2^{-}}, \mathrm{E} 1_{3^{-}}, \mathrm{E} 1_{5^{-}}$and total PRL-R mRNAs and GAPDH mRNA with four rats in each group. (B) Densities of the hybridization signals were measured and expressed as values relative to the value of each PRL-R mRNA of the sham-operated group. Each value represents the mean \pm S.D. ${ }^{* *} P<0.01,{ }^{* \star *} P<0.001$ vs the sham-treated group. Cast, castrated.

PRL-R gene by cDNA and genomic DNA clonings, and found to be localized in the most proximal position to exon $2 . \mathrm{E}_{5}$ was preferentially expressed in the liver, brain and kidney. Such an expression profile differs from those of any other known first exons of rat and human PRL-R genes. Mouse counterparts of rat $\mathrm{E} 1_{1}, \mathrm{E} 1_{2}, \mathrm{E} 1_{3}$ and $\mathrm{E} 1_{5}$ are found in the $5^{\prime}$-flanking region of exon 2 of mouse PRL-R gene contained in a bacterial artificial chromosome clone derived from mouse chromosome 15. Although mouse $\mathrm{E} 1_{1}$ and $\mathrm{E} 1_{3}$ have been shown to be expressed in a mouse Leydig tumour cell line (Hu et al. 1997), expression profiles of each first exon in mouse tissues are not known. In the rat liver, $\mathrm{E} 1_{2}$ and $\mathrm{E} 1_{3}$ are also expressed with $\mathrm{E}_{2}$ as the major form $(\mathrm{Hu}$ et al. 1996). It has been shown that the expression of $\mathrm{E} 1_{2}$ in the liver depends on the action of HNF4 on the 
promoter (Hu et al. 1998b) and that the expression of $\mathrm{E} 1_{3}$ in a wide range of tissues including the liver is operated by the activation of the promoter with the generic transcription factors, $\mathrm{C} / \mathrm{EBP} \beta$ and $\mathrm{SP} 1$ (Moldrup et al. 1996). Within the $1.5 \mathrm{~kb} 5^{\prime}$-flanking region of $\mathrm{E} 1_{5}$, there is no consensus element for these transcription factors participating in the activation of $\mathrm{E} 1_{2}$ or $\mathrm{E}_{3}$. CGAAT, GATA and GAS elements are present, but no canonical TATA box or GC box exists in the 5'-region. The promoter regions directing the preferential expression in the liver, brain and kidney remain to be investigated.

It is well known that PRL-R is abundantly present in the female rat liver and that sex steroid hormones strongly affect the expression levels of PRL-R in the liver (Norstedt \& Mode 1982, Yasui et al. 1999). We have previously shown that the PRL-R gene expression increases and decreases during sexual maturation in female and male rat liver respectively (Sakaguchi et al. 1994). The mRNA levels in the female liver decreased with ovariectomy and were restored by the administration of oestrogen. On the other hand, castration of male rats resulted in the induction of the PRL-R gene expression, and testosterone completely blocked the induction of the gene expression. Our present study revealed that expression of the three PRL-R mRNA species containing $\mathrm{E}_{2}, \mathrm{E}_{3}$ or $\mathrm{E} 1_{5}$ first exons were distinctly regulated by sex steroid hormones in the liver. In the female, the levels of $\mathrm{E} 1_{2}$-PRL-R mRNA markedly increased during sexual maturation while, in the male, the mRNA levels were very low irrespective of sexual maturation. E1 ${ }_{5}$-PRL-R mRNA levels in both sexes decreased during sexual maturation with male rats showing the higher extent. No notable change was observed in the levels of $\mathrm{E} 1_{3}$-PRL-R mRNA with sex or age. In female rat liver, oestrogen treatment after ovariectomy resulted in the up-regulation of $\mathrm{E} 1_{2}$-PRL-R mRNA expression and the down-regulation of $\mathrm{E} 1_{5}$ PRL-R mRNA expression. In male rat liver, testosterone treatment following castration showed a strong and moderate suppression of the expression of $\mathrm{E}_{2^{-}}$and $\mathrm{E}_{5}$-PRL-R mRNAs respectively. The expression of $\mathrm{E} 1_{3}$-PRL-R mRNA was not affected by treatment with sex steroid hormones in either sex. The expression profiles of the total PRL-R mRNA in both sexes were represented by the profile of $\mathrm{E}_{2}{ }_{2}$-PRL-R mRNA, consistent with the reported finding that $\mathrm{E} 1_{2}$-PRL-R mRNA is the most abundant PRL-R mRNA species in the liver (Hu et al. 1996). The presence of two potential half sites of the oestrogen-responsive element in the promoter region of $\mathrm{E}_{2}$ ( $\mathrm{Hu}$ et al. 1996) suggested the possibility of a direct effect of oestrogen on $\mathrm{E}_{2}$ expression. The molecular mechanisms of the inducible effect of oestrogen together with the suppressive effect of androgen on $\mathrm{E} 1_{2}$ expression in the liver remain to be elucidated.
In addition to hepatocytes, the liver contains several cell types such as Kupffer cells, endothelial cells and hepatic stellate cells with minor populations. It has been shown that PRL-R is largely expressed in hepatocytes in the rat liver with higher levels in the female than in the male and that the PRL-R levels increase and decrease in both sexes with oestrogen and androgen treatments respectively (Smirnova et al. 1994). More recently, PRL-R gene expression has been observed in Kupffer cells as well as in hepatocytes in the male rat liver (Yokoyama et al. 2003). Although the profiles of the first exon usage in each cell types in the liver are not known, our present findings suggest that the $\mathrm{E} 1_{2}$ first exon is largely responsible for the stimulative and depressive effects of sex steroid hormones on the levels of PRL-R mRNA in hepatocytes. Moreover, it can be speculated that $\mathrm{E} 1_{3}$ and $\mathrm{E} 1_{5}$ are used in the minor hepatic cells to show the differential effects on their expression by sex steroid hormones.

In conclusion, the expression of the PRL-R gene in the liver is regulated by sex steroid hormones with different effects on the transcription of $\mathrm{E} 1_{2}, \mathrm{E} 1_{3}$ and the newly identified $\mathrm{E} 1_{5}$ first exons. Oestrogen moderately increases the overall PRL-R mRNA level in the female liver by stimulating the expression of $\mathrm{E} 1_{2}$ mRNA, while the overall PRL-R mRNA level in the male liver is strongly depressed by testosterone due to the suppression of $\mathrm{E} 1_{2}$ and $\mathrm{E} 1_{5}$ mRNA expression. These findings contribute to the understanding of the regulatory mechanisms of PRL-R gene expression by sex steroid hormones in the liver.

\section{Acknowledgements}

This work was supported in part by the grants-in-aid for Scientific Research 15380203 from the Ministry of Education, Science, Sports and Culture of Japan. The authors declare that there is no conflict of interest that would prejudice the impartiality of this scientific work.

\section{References}

Bignon C, Binart N, Ormandy C, Schuler LA, Kelly PA \& Djiane J 1997 Long and short forms of the ovine prolactin receptor: cDNA cloning and genomic analysis reveal that the two forms arise by different alternative splicing mechanisms in ruminants and in rodents. Fournal of Molecular Endocrinology 19 109-120.

Boutin JM, Jolicoeur C, Okamura H, Gagnon J, Edery M, Shirota M, Banville D, Dusanter-Fourt I, Djiane J \& Kelly PA 1988 Cloning and expression of the rat prolactin receptor, a member of the growth hormone/prolactin receptor gene family. Cell 53 69-77.

Davis JA \& Linzer DI 1989 Expression of multiple forms of the prolactin receptor in mouse liver. Molecular Endocrinology 3 $674-680$.

Doppler W 1994 Regulation of gene expression by prolactin. Reviews of Physiology, Biochemistry and Pharmacology 124 93-130. 
Freeman ME, Kanyicska B, Lerant A \& Nagy G 2000 Prolactin: structure, function, and regulation of secretion. Physiological Revieres 80 1523-1631.

Hu Z, Zhuang L \& Dufau ML 1996 Multiple and tissue-specific promoter control of gonadal and non-gonadal prolactin receptor gene expression. Fournal of Biological Chemistry 271 10242-10246.

Hu Z, Zhuang L, Guan X, Meng J \& Dufau M 1997 Steroidogenic factor-1 is an essential transcriptional activator for gonad-specific expression of promoter I of the rat prolactin receptor gene. Fournal of Biological Chemistry 272 14263-14271.

Hu Z-Z, Zhuang L \& Dufau ML 1998a Prolactin receptor gene diversity: structure and regulation. Trends in Endocrinology and Metabolism 9 94-102.

Hu Z-Z, Zhuang L, Meng J \& Dufau ML 1998b Transcriptional regulation of the generic promoter III of the rat prolactin receptor gene by $\mathrm{C} / \mathrm{EBP} \beta$ and SP1. Fournal of Biological Chemistry 273 26225-26235.

Hu ZZ, Zhuang L, Meng J, Leondires M \& Dufau ML 1999 The human prolactin receptor gene structure and alternative promoter utilization: the generic promoter hPIII and a novel human promoter $\mathrm{hP}(\mathrm{N})$. Foumal of Clinical Endocrinology and Metabolism 84 $1153-1156$.

Hu ZZ, Zhuang L, Meng J, Tsai-Morris CH \& Dufau ML 2002 Complex $5^{\prime}$ genomic structure of the human prolactin receptor: multiple alternative exons 1 and promoter utilization. Endocrinology $1432139-2142$.

Jolicoeur C, Boutin JM, Okamura H, Raguet S, Djiane J \& Kelly PA 1989 Multiple regulation of prolactin receptor gene expression in rat liver. Molecular Endocrinology 3 895-900.

Kelly PA, Djiane J, Postel-Vianay MC \& Edery M 1991 The prolactin/growth hormone receptor family. Endocrine Reviews 12 235-251.

Maruyama K \& Sugano S 1994 Oligo-capping: a simple method to replace the cap structure of eukaryotic mRNAs with oligoribonucleotides. Gene 138 171-174.

Moldrup A, Ormandy C, Nagano M, Murthy K, Banville D, Tronche F \& Kelly PA 1996 Differential promoter usage in prolactin receptor gene expression: hepatocyte nuclear factor 4 binds to and activates the promoter preferentially active in the liver. Molecular Endocrinology $10661-671$.

Norstedt G \& Mode A 1982 On the primary site of action of estrogens and androgens in the regulation of hepatic prolactin receptors. Endocrinology 111 645-659.
Ochman H, Medhora MM, Garza D \& Hartl DL 1990 Amplification of flanking sequences by inverse PCR. In PCR Protocols, pp 219-227. Eds MA Innes, DH Gelfand, JJ Sninsky \& TJ White. San Diego: Academic Press.

Pi X, Zhang B, Li J \& Voogt JL 2003 Promoter usage and estrogen regulation of prolactin receptor gene in the brain of the female rat. Neuroendocrinology 77 187-197.

Sakaguchi K, Ohkubo T, Sugiyama T, Tanaka M, Ushiro H \& Nakashima K 1994 Differential regulation of prolactin receptor mRNA expression in rat liver and kidney by testosterone and oestradiol. Fournal of Endocrinology 143 383-392.

Schuler LA, Nagel RJ, Gao J, Horseman ND \& Kessler MA 1997 Prolactin receptor heterogeneity in bovine fetal and maternal tissues. Endocrinology 138 3187-3194.

Shirota M, Banville D, Ali S, Jolicoeur C, Boutin JM, Edery M, Djiane J \& Kelly PA 1990 Expression of two forms of prolactin receptor in rat ovary and liver. Molecular Endocrinology 4 1136-1143.

Smirnova OV, Petraschuk OM \& Kelly PA 1994 Immunocytochemical localization of prolactin receptors in rat liver cells: I. Dependence on sex and sex steroids. Molecular and Cellular Endocrinology 105 77-81.

Sugiyama T, Minoura H, Kawabe N, Tanaka M \& Nakashima K 1994 Preferential expression of long form prolactin receptor mRNA in the rat brain during the oestrous cycle, pregnancy and lactation: hormones involved in its gene expression. Fournal of Endocrinology 141 325-333.

Tanaka M, Hayashida Y, Iguchi T, Nakao N, Suzuki M, Nakai N \& Nakashima K 2002 Identification of a novel first exon of prolactin receptor gene expressed in the rat brain. Endocrinology 143 2080-2084.

Yasui T, Murakami T, Maeda T \& Oka T 1999 Involvement of gonadal steroid hormone disturbance in altered prolactin receptor gene expression in the liver of diabetic mice. Fournal of Endocrinology $16133-40$.

Yokoyama Y, Kitchens WC, Toth B, Schwacha MG, Bland KI \& Chaudry IH 2003 Upregulation of hepatic prolactin receptor gene expression by 17 beta-estradiol following trauma-hemorrhage. Journal of Applied Physiology 95 2530-2536.

Received 3 December 2004

Accepted 8 March 2005

Made available online as an Accepted Preprint 21 March 2005 